\title{
Report of the Technical Review Team on the \\ Catalytic Extraction Process*
}

* Developed by Molten Metal Technology, Inc.

March 1996

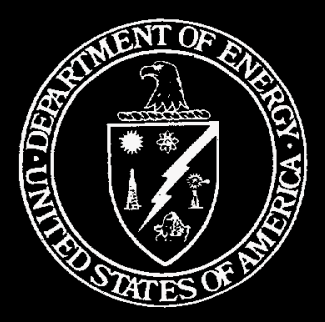

U.S. Department of Energy

Office of Science and Technology

Office of Environmental Management 


\section{DISCLAIMER}

This report was prepared as an account of work sponsored by an agency of the United States Government. Neither the United States Government nor any agency thereof, nor any of their employees, makes any warranty, express or implied, or assumes any legal liability or responsibility for the accuracy, completeness, or usefulness of any information, apparatus, product, or process disclosed, or represents that its use would not infringe privately owned rights. Reference herein to any specific commercial product, process, or service by trade name, trademark, manufacturer, or otherwise does not necessarily constitute or imply its endorsement, recommendation, or favoring by the United States Government or any agency thereof. The views and opinions of authors expressed herein do not necessarily state or reflect those of the United States Government or any agency thereof.

This report has been reproduced directly from the best available copy.

Available to DOE and DOE Contractors from the Office of Scientific and Technical Information, P.O. Box 62, Oak Ridge, TN 37831; prices available from (423) 576-8401.

Available to the public from the U.S. Department of Commerce, Technology Administration, National Technical Information Service, Springfield, VA 22161, (703) $487-4650$ 


\section{Report of the Technical Review Team on the}

\section{Catalytic Extraction Process*}

* Developed by Molten Metal Technology, Inc.

\section{March 1996}

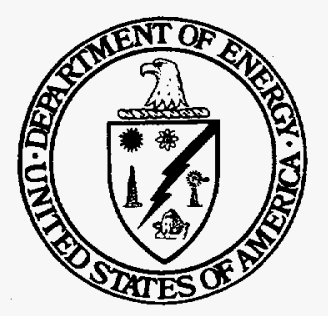

U.S. Department of Energy

Office of Science and Technology

Office of Environmental Management

Washington, DC 20585 


\section{DISCLAIMER}

This report was prepared as an account of work sponsored by an agency of the United States Government. Neither the United States Government nor any agency thereof, nor any of their employees, makes any warranty, express or implied, or assumes any legal liability or responsibility for the accuracy, completeness, or usefulness of any information, apparatus, product, or process disclosed, or represents that its use would not infringe privateiy owned rights. Reference herein to any specific commercial product, process, or service by trade name, trademark, manufacturer, or otherwise does not necessarily constitute or imply its endorsement, recommendation, or favoring by the United States Government or any agency thereof. The views and opinions of authors expressed herein do not necessarily state or reflect those of the United States Government or any agency thereof. 


\section{DISCLAIMER}

Portions of this document may be illegible in electronic image products. Images are produced from the best available original document. 


\section{Foreword}

The U.S. Department of Energy's (DOE) Office of Science and Technology (formerly Office of Technology Development) has explored many new and innovative ways to treat radioactive/ hazardous wastes, called mixed wastes, now stored at its various sites. One of the methods to which funds have been provided for $R \& D$ purposes is based on steel-making and related metallurgical processes. Applications of this method to mixed low-level waste has been explored by Molten Metal Technology, Inc., in response to a DOE Program Research and Development Announcement.

The process, called Catalytic Extraction Process (CEP) can treat a variety of liquid, pumpable, and solid waste which has undergone size reduction. The treatment disassociates the organic constituents in the waste and reduces them to a combustible gas stream. Inorganic chemical and radioactive constituents remain as solids in the form of metallic and slag phases. An initial charge of metal (usually iron) is melted by induction heating to form a metal bath. The waste is introduced below the surface of a molten metal bath within a refractory-lined vessel. In the bath, waste constituents separate into metallic and oxide slag/ceramic layers, and offgas products. The separation of metals from the slag depends on thermodynamic properties of the constituents, process additives or reagents, and the operating environment. Both the metal and slag can be drawn from the crucible. Conceptually, the relatively pure metal can be recycled and reused. The oxide slag containing most of the radionuclides can be sent to disposal or recycled if a use exists. Offgases from the crucible, containing principally carbon monoxide and hydrogen, are filtered, treated, and cleaned. They are then used for fuel or oxidized before release to the environment.

Organics are decomposed by the intense bath heat (up to $1600^{\circ} \mathrm{C}$ ) and the effects of the metal solvent. Carbon dissolves in the metal bath. Destruction efficiencies exceed $99.9999 \%$ (six 9's) with proper residence time below the bath surface. The process is capable of treating a wide variety of waste, simultaneously destroying organics, and decontaminating and partitioning metal constituents.

The status of the development of CEP was the subject of this review. 


\section{Executive Summary}

During a technical review on January 23 and 24, 1996, the DOE Technical Review Team (TRT) was impressed with the amount and quality of work that has been done since the last review in January 1995 by a DOE Technical Review Panel (TRP). MMT has been responsive to recommendations of the TRP made in 1995. MMT has made good progress in addressing the special concerns of the TRP for the processing of DOE mixed low-level waste (MLLW) as required by the present PRDA contract. Advancement of the technology has been accomplished on the R\&D front as well as the actual implementation of the Catalytic Extraction Process (hereinafter, "CEP") technology through its subsidiary with partner Lockheed Martin Corporation, called M4 Environmental, L.P. (or "M4"), at Oak Ridge, TN. The M4 facilities, now operating on actual radioactive waste, exemplify the capability of private industry to take the initiative and move forward to design and construct facilities using technical results from DOEfunded $R \& D$ activities.

The TRT reviewed the status of the CEP technology development and its readiness for application. The TRT did not specifically review the status of performance under the existing contract because the final reports have not been prepared. The TRT did not address or review the industrial venture by M4 but focused on the research and development effort performed by MMT at its Fall River, Mass., facility.

Given the favorable results of MTT's work on CEP over the last year and given the implementation of the MMT/M4 industrial venture, the TRT found the CEP technology to be sufficiently developed that MMT should be able to compete in the marketplace by adapting CEP for processing DOE's various types of mixed low level waste (MLLW). Although additional development work is needed for specific applications, work on those applications should accompany the specific needs at the particular site possessing the waste.

The TRT, however, believes that the application of CEP to specific wastes other than the broad category of MLLW has not been fully explored. Applications to TRU waste and to HLW are not fully developed or explored. Assessment of these applications is needed in comparison to other competing processes. Specifically, R\&D is needed as follows: 
1. For Transuranic (TRU) waste, no policy has been established for treatment. For research and development, however, an understanding is needed of the partitioning of plutonium and other fissile isotopes between the metal and ceramic phases and into the air pollution control system in order to address criticality issues and associated design requirements.

2. For High Level Waste (HLW), the applications to the concepts and designs for Hanford, INEL, and SRS need to be assessed in comparison to other options. The potential role of MMT for these applications is not clear or fully explored. Mass and energy balances and associated cost estimates are needed to indicate whether CEP is applicable.

Based on the information provided, the TRT made the following observations:

CEP offers:

processing of pumpable MLLW and shredded MLLW to disassociate and reduce the organic constituents

processing of MLLW under reducing conditions that will not produce dioxins or furans

accumulation of metals that can be withdrawn and recycled for reuse as long as the composition of the iron bath remains within acceptable limits for use. The withdrawn metals should be used to fabricate containers for disposal of the immobilized ceramic waste

accumulation of the more volatile metals, e.g. mercury, in the metallic form through gasphase recovery techniques for potential purification and recycle

accumulation of incoming lead mostly as dust from the baghouse, presumably as elemental lead, lead oxide, or a chloride if chlorine is present in the feed, which could be incorporated into polyethylene or other suitable waste form for disposal 
production of a slag ${ }^{1}$ type waste form that passes TCLP tests and renders the waste to be classified as a radioactive waste for disposition by $\mathrm{DOE}$

production of separate dust and salt streams that may be incorporated into a polyethylene or other suitable waste form (This is typical of all current thermal treatment systems that are candidates for DOE MLLW treatment.).

CEP has the following uncertainties:

processing of shredded waste will likely require feeding on the top of the molten metal and will require a second stage to destroy the organic vapors from the first stage

all of the design concepts required for operation with radioactive material have not been assembled or tested, for example, the containment and melt discharge systems and their remote operational requirements (This is similar to most other competitive concepts that also have not demonstrated this step.)

the life of the ceramic liner varies from an estimated 90 days at the melt interfaces to 180 days in the metal melt or vapor phase

although operation under pressure (175 psig) is thought to be somewhat better to control dust carry-over from the melter, operations can also be conducted under atmospheric conditions that allow the customary slightly negative pressures within the system for containment of radionuclides

the composition of the slag, preferably using calcium and silicate, needs to be more precisely defined to establish whether the compositions can be maintained or adjusted to the viscosity needed for tapping into a final waste container

1 "Slag" is a common term used in the metals industry. CEP's "slag" contains non-metal components; hence MMT, Inc. uses the term "ceramic". "Ceramic" is used throughout this report. 
the endothermic nature of the reaction may require supplemental heat besides induction heating of the melt for bulk feeding applications

the amount of sorting and control needed to maintain the molten metal within a useable composition range as varying metals are processed through the unit, particularly the introduction of copper, needs to be determined

the amount of dust and the scrubber saits that must be incorporated into polyethylene or other waste form suitable for disposal needs quantification

the chemical complexity in the metal bath and ceramic layers introduces control questions that will require good characterization of incoming waste or the incorporation of real-time composition analysis capabilities.

processing of whole drums appears to be an unlikely option for MLLW, but shredded waste up to 2-5 inch size may be possible if fully tested

the absence of DOE policy on waste forms creates an uncertainty concerning the value/benefit and acceptability of final products from CEP as well as all other treatment processes

The information provided was insufficient to determine the effluent quantities and compositions of metal discharged from the melt. Likewise, judgement could not be made on the amounts of slag layer including possible glass-forming additives that would be generated. Further, the amount of dust that would be discharged with or without recycle of dust back into the molten metal was not known. Finally, the amount of effluent gases and liquids that would be generated from the system should be known. This type of information is critical in judging the performance of this process against other treatment options.

The TRT noted that a major task in gaining acceptance of technologies such as CEP is communicating sufficient technical information to DOE technical staff, stakeholders, and general public groups on actual processing performance. This information needs to include not only material balances but also analytical information on all effluents during normal and upset 
conditions that has been validated by continuous emission monitoring and actual analysis at EPA certified laboratories. This information must include the collection or absence of materials in backup HEPA and carbon filters. The tendency to maintain this type of information as proprietary does not support gaining trust and acceptance by stakeholders, tribal, and public interest groups.

The TRT recognizes that an extended run feeding typical DOE MLLW (using surrogates for the rad portion) has not been conducted. Until this is done, all the DOE decision maker is left with are theoretical calculations and results from short-term surrogates studies.

Specific observations of the TRT include:

\section{Bulk Processing.}

Through DOE-sponsored development, MMT has provided perspectives on the method to be used for bulk processing. Although additional testing is still required, MMT believes that shredded waste of approximately 2-5 inch size can be fed onto the surface of the molten metal bath and be effectively processed if a second stage is used for contacting gases from the first stage. Either two separate baths or a single stage designed with a baffle or weir are possible. The TRT was pleased to see MMT has begun work to design such a concept. However, additional work remains on the design and operating efficiency of the single stage baffle or weir design. This capability might move CEP into competition with many incineration operations that also use shredded waste with approximately the same size of shredding. In doing so, MMT has eliminated the need for costly fine grinding of MLLW. Shredding also offers the capability to homogenize the waste before processing if needed. The shredding concept allows taking the vapors from the shredding operation and processing them directly through the molten metal bath.

\section{Partitioning.}

Data accumulated on CEP have shown that certain materials will accumulate in the metal phase, including sulfur, phosphorus, technetium, and cobalt. Other materials readily transfer to the ceramic phase. Such transfers are composition-sensitive and require adjustments if advantages are recognized. 


\section{Air Pollution Control Subsystem.}

The more volatile metals (e.g., lead, zinc, and mercury) will be volatilized to the air pollution control system (APC). In the absence of a ceramic layer, all except a few percent of the chlorine transfers to the APC -- about 50\% is in the form of ferrous chloride dust and the remainder as $\mathrm{HCl}$ that is neutralized in the caustic scrubber and requires disposition as chloride salt. The mercury volatizes and is collected in the scrubber. There is some indication that elemental $\mathrm{Hg}$ can be removed from the scrubber for potential purification and reuse. The first stage filtration of dust after a quenching step can be either a bag house or a ceramic filter. The dust must be either recycled or a side stream of dust removed for stabilization and disposal.

\section{Waste Form.}

The ceramic waste form produced by CEP can be quite variable in composition and needs to be optimized in order to understand 1) the most attractive compositions, 2) resulting volumes, and 3) final waste form (slag or glass) that should be used. Optimization is linked to the need for DOE to understand which waste forms are good enough for long term storage and disposal and the development of waste acceptance criteria for disposal. Until DOE takes a position on the quality of final waste forms required, considerable flexibility will exist. DOE needs to address the waste form issue to determine performance required relative to the type of disposal environment. Further, recommendations should be developed on the type of waste form testing to be used.

\section{Waste Product Removal.}

The tapping procedure for the slag and the metal are not clear for remote operation of CEP on radioactive wastes (called Q-CEP), particularly in the presence of alpha contamination. Freeze valves for tapping the reactor are being designed and tested. Batch operations compared to continuous flow designs are currently in use at one Q-CEP facility, but the approach to operating pressures within the processing chamber influences this design approach. The design approach must accommodate the need to contain the vapors during the tapping operation. The discharge of bulk quantities of slag to drums for disposal and the desired cooling rate have not yet been defined. 


\section{Dust and Volatiles.}

Dust and volatiles emitted from the molten metal and slag phases must be low enough in volume to send them directly to immobilization (e.g., potentially microencapsulation in polyethylene). Alternatively, recycle of the accumulated dust and volatiles must be understood and planned along with the appropriate removal of a side stream for microencapsulation and disposal.

\section{Containment.}

Processes such as CEP require special care in designing containment because of the potential for explosive situations if the internal gas compositions are not carefully controlled. Protection against in-leakage of air is necessary, or the total containment of the equipment using an inert gas blanket.

\section{Reliability.}

Operating experience is lacking to predict the reliability of CEP. Time and motion studies are not complete to predict the operating efficiency. These studies will likely not be available until more industrial experience is obtained.

\section{Process Chemistry.}

As more is understood about CEP, the chemistry becomes rather complex and may require specific adjustments and control. Significant progress has been made in understanding the accumulation of material in the metal melt and in the floating slag phase. This complexity and the associated increases in viscosity of the ceramic phase require determining whether glass formers should be added to maintain the viscosity. While viscosity can be designed for known waste compositions, it imposes the requirement of good characterization of the incoming waste. If the waste is not well characterized, the unknown compositions can lead to attempts to operate the unit outside of the requisite compositions and operating conditions for discharge of the slag phase or the metal. Currently, it appears imperative that the compositions of the incoming waste be either well known, or the system operators will need to make modifications to the system chemistry before product removal. 


\section{Future Contractual Arrangements.}

Most of the technologies capable of processing MLLW still have a number of unknowns and a lack of operating experience. A number of issues and problems should be expected during the start up and operation of a facility. In planning contracts, it is essential that "on-the-spot" adjustments and development tests accompany the start up of a facility. Sufficient time should be allowed for this shakedown. The CEP is no exception to this approach.

Instrumentation.

CEP seems to be well-instrumented; however, as in any pioneering technology, work continues to improve on-line, real-time measurements of operational parameters. This is especially true when it comes to measuring characteristics (e.g., viscosity) of the ceramic layer to ensure that various changes do not adversely affect the desired product for discharge to disposal containers. 
Table of Contents

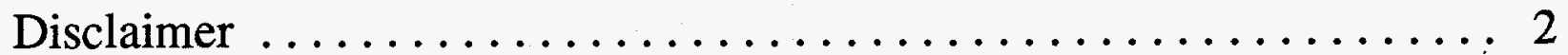

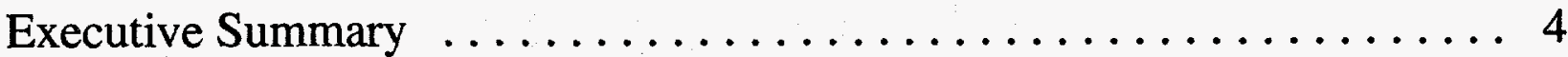

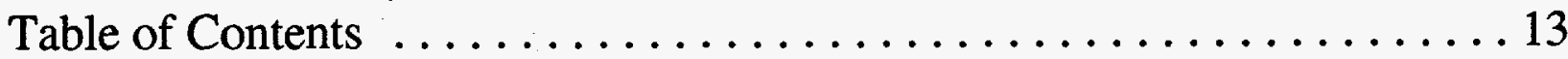

Acknowledgments ................................. 15

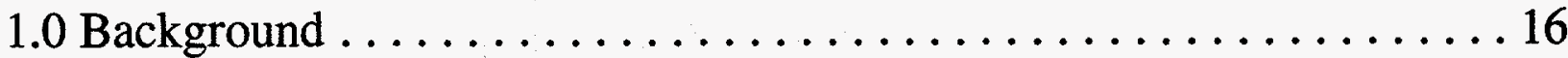

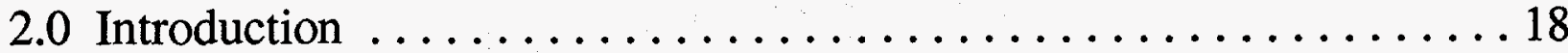

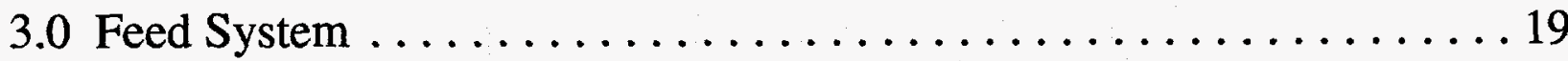

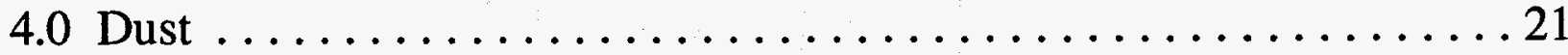

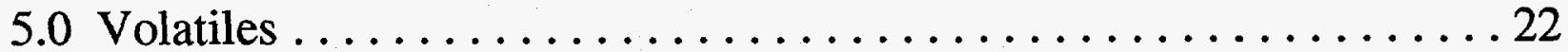

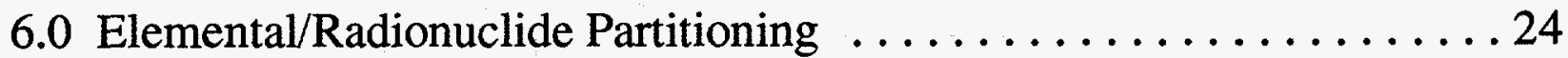

6.1 Volatile/Semi-Volatile Species .................... 24

6.2 Oxidized Species . . . . . . . . . . . . . . . . . . 26

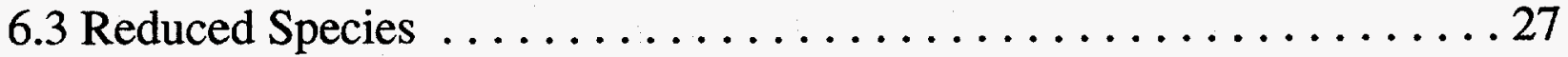

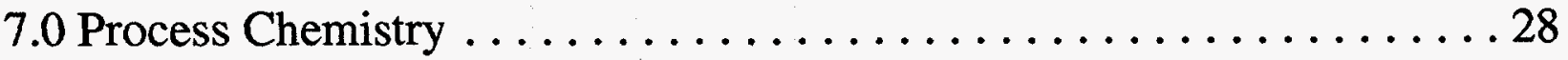

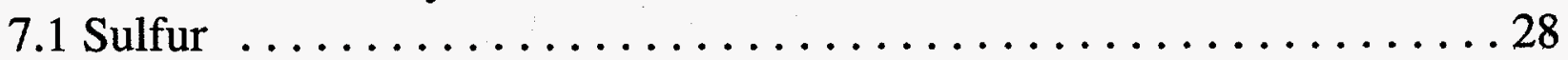

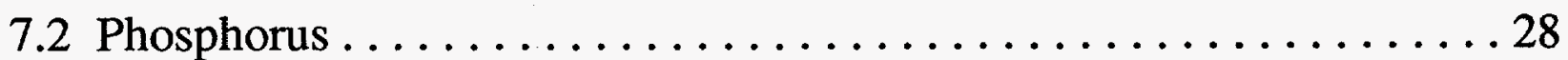

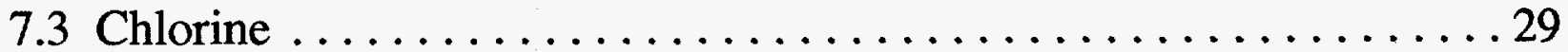

8.0 Final Waste Form . . . . . . . . . . . . . . . . . . 30

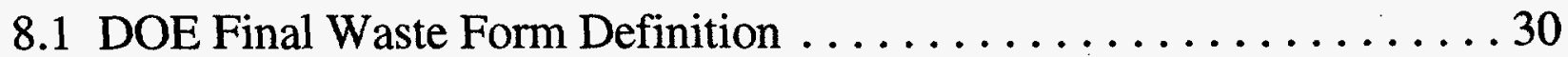

9.0 Further Research . . . . . . . . . . . . . . . . . . . . . 32

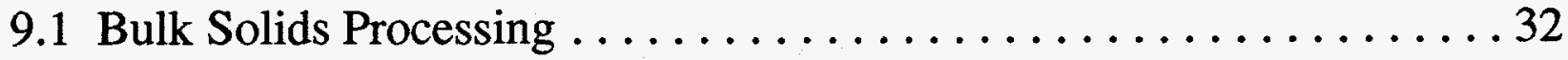

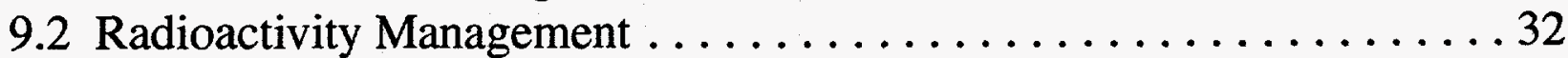

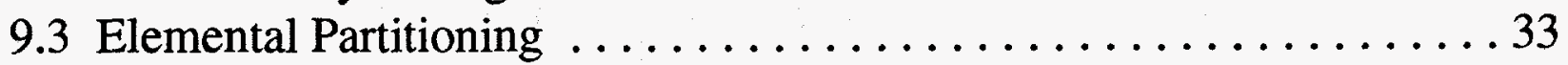




\section{TABLE OF CONTENTS (continued)}

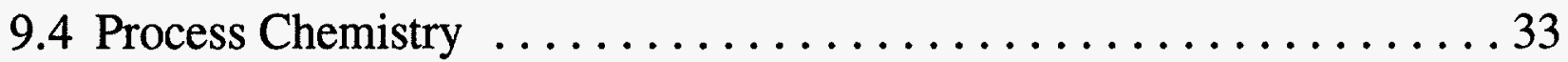

9.5 Alternative Energy Addition . . . . . . . . . . . . . . . . . 33

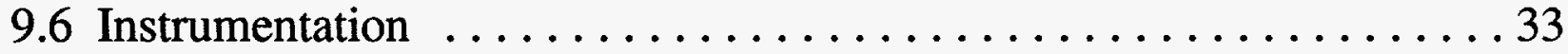

9.7 Product Quality . . . . . . . . . . . . . . . . . . . . . . . 34

9.8 Containment Systems . . . . . . . . . . . . . . . . . . . . 34

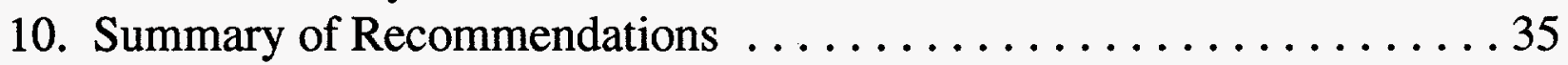

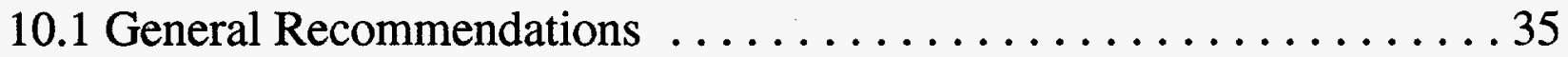

10.2 Positive Attributes Noted . . . . . . . . . . . . . . . . . . 35

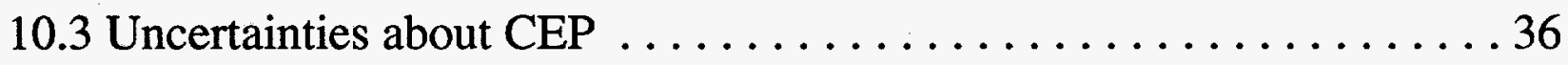

11.0 Follow Up of TRP Issues $\ldots \ldots \ldots \ldots \ldots \ldots \ldots \ldots \ldots \ldots$

APPENDIX A (Biographies of TRT) $\ldots \ldots \ldots \ldots \ldots \ldots \ldots \ldots \ldots 40$ APPENDIX B (Jan. 1996 Agenda of TRT Review Session at MMT) . ... 58 APPENDIX C (Attendance List at Jan. 1996 Review Session) . . . . . . . . 59 APPENDIX D (Acronyms and Abbreviations) $\ldots \ldots \ldots \ldots \ldots \ldots 60$ 


\section{Acknowledgments}

The Technical Review Team would like to thank the staff of Molten Metal Technology, Inc. (MMT) for its forthrightness and dedication in sharing their knowledge with the TRT. It would like to thank William Huber, DOE-METC, for attending the review and sharing with the team his background, experience, and perspective. The Team would also like to thank Gary Knight of WPI for arranging the logistics of the meeting and for his pulling together our various views into this report. Finally, the TRT would like to thank Dr. Clyde Frank, EM-50, for his guidance and leadership. 


\subsection{Background}

The present review is a follow-on to that conducted a year ago by the U.S. Department of Energy's (DOE) Office of Environmental Management (EM). That review by the Office of Technology Development (now, the Office of Science and Technology) was conducted by a Technical Review Panel (TRP) comprised of eight DOE scientists and engineers and one EPA regulator. The present Technical Review Team (TRT) was comprised of four DOE headquarters and field staff from the TRP and one additional DOE field engineer (see biographies in Appendix A). The Team was chaired by Carl R. Cooley, EM-50. Also on the Team were the following: Scott Boeke, DOE-OR; Dr. Edwin A. Korzon, DOE-SR; William A. Owca, DOE-ID; and Michael A. Torbert, EM-34. The same support contractor person was used. The TRP review consisted of reviewing reports, touring the Molten Metal Technology Inc. (MMT) plant at Fall River, MA on January 17, 1995, and participating in interactive presentations with MMT staff. The TRT visited the Fall River pilot plant January 23-24, 1996, for extensive briefings (see agenda in Appendix B and attendees in Appendix C).

Although MMT's Catalytic Extraction Process (CEP) has numerous potential applications, both the TRP and this review focused on establishing "a better understanding of the likely application of CEP to DOE mixed low-level waste (MLLW), including contact-handled mixed low level wastes (CH-MLLW), contact-handled transuranic mixed wastes (CH-TRU), and remote-handled transuranic mixed wastes (RH-TRU) at DOE sites and to identifying future development activities". (As shorthand in this report, "wastes" will refer to the foregoing types of DOE wastes unless otherwise specified.) Since the TRP review, MMT has now developed Quantum-Catalytic Extraction Process (or Q-CEP, for application on wastes containing radioactive components) in conjunction with its partner Lockheed Martin Corporation in a joint venture called M4 Environmental, L.P. (M4).

As in the TRP report, comments by the TRT members are directed toward CEP application on DOE-specific radioactive waste and do not apply -- nor should they be construed to apply -- to non-DOE applications. 
The specific purposes established for the 1995 TRP review included:

1)

Assess the performance of CEP on the destruction of hazardous wastes conducted to date particularly on tests performed with DOE financial support (although in both the TRP and TRT reviews, MMT also shared condensed results of $R \& D$ work funded through other means);

2)

Provide professional judgement on whether, given available data, CEP is a good candidate for application to DOE CH-MLLW, CH-TRU, and RHTRU or a particular portion of DOE CH-MLLW, CH-TRU, and RH-TRU; and

3)

Identify R\&D needs requisite for possible application on DOE wastes, mixed, or other.

As before, this TRT review is simply an up-date of the previous review. Again, the TRT focused on process performance including: bulk solids feeding, radioactive partitioning, process chemistry, dust and volatiles, containment, final waste forms, product removal (tapping of melt from the reactor), and instrumentation. Costs were not requested nor considered. Future DOE procurement processes will determine if CEP is competitive with other treatment systems as DOE sites issue RFPs for systems to treat their MLLW. Lastly, this was not a safety review.

At the time of the TRP review, MMT was performing work on bulk feeding as part of the requirements of the second phase of DOE PRDA Contract DE-AC31-93MC30171. While such work was described by MMT, no attempt was made by the TRT to verify such work. The DOEMETC contracting officer representative was the observer at both the TRP and TRT reviews. 


\subsection{Introduction}

The TRT was impressed with the quality and volume of laboratory and pilot scale development work that had been conducted over the past year. Many of the doubts and questions raised by the TRP on technical details had been examined, either by theoretical calculations or in the pilot facility. Moreover, a more open and forthcoming attitude was evident among the MMT staff who either presented briefings or responded to the Team's questions.

Of special note to DOE, the TRP recognized a year ago that the pilot facility at Fall River was not designed for radioactive pilot tests. However, from the dialogue surrounding the TRP review, it was evident that not much thought had been given to the hazards, concerns, and special requirements incumbent with radioactive operations -- everything from doing pours of hot radioactive metal from a vessel to remote-handling equipment and operations. This year the TRT noticed a significant improvement in this respect.

As before, the TRT was impressed by the quality of engineering evident in MMT plans and tests. MMT is to be commended for this quality and is urged to carry over this high standard into the actual operation of its facilities, once constructed.

As was stated above, MMT has now partnered with Lockheed Martin to form M4 Environmental, L.P. (or "M4") for purposes of pursuing commercial work on DOE waste operations. As such, within the past month, working with DOE headquarters personnel from EM-30 and 50, and with DOE-OR employees and contractors, M4 demonstrated CEP on 200-300 pounds of DOE-OR MLLW. Results of the tests are being awaited. Simultaneously, MMT is building with SEG, Inc. of Oak Ridge a facility to process spent ion exchange resins from commercial power plants. Also, with its own funds and on its own land, M4 is constructing a combination or "combo" plant in the Oak Ridge, TN, area to conduct radioactive tests and to actually process MLLW. 


\subsection{Feed System}

MMT reported on progress to determine the operating parameters for processing bulk solids using the MMT process. It is anticipated that top charging will be utilized for bulk feed with a two zone system. The two zones may consist of designs using either two baths in series or a baffled single bath. The purpose of the second zone being reaction of the gases before entering the scrubbers and filters used for offgas cleaning. It was indicated that present charge systems can handle 1 " to 2 " uncharacterized materials. It was determined that four-inch diameter volatile materials, $12^{\prime \prime}$ diameter ceramic or concrete, and 12" diameter metals can be processed using present technology. MMT is currently investigating the use of feed lock hopper devices and screw feeders for potential future application as bulk feed devices in addition to large bore lances for injection of shredded waste. Injection of shredded waste brings CEP to the point of being a more versatile process for MLLW.

Additional engineering development is needed if CEP is to treat uncharacterized 55 gallon drums of waste. The cost and need for this capability should be considered further by DOE before doing further development work on whole drum feeding. Shredding uncharacterized drums of LLW, consisting of the typical mix of solid and liquid materials in most LLW, may be more efficient and less costly then pursuing an uncharacterized drum feed capability for that type waste. As long as CEP can accept shredded materials but can avoid grinding, CEP should be competitive with other treatment methods. Obviously, additional testing is needed on the performance of the feeding equipment whether waste is fed on the surface or injected into the molten bath.

MMT reported that the use of lances (injecting below the surface of the melt from the top) for bottom feeding solid types of waste had progressed significantly since last year. The bottom feeding allows the use of one reaction zone instead of two. A two and one-half inch I.D. lance has been operated successfully, according to MMT. This size lance may be able to feed shredded solid waste that can be readily produced in one to two-inch sizes by a number of commercially available waste shredders. 
The present MMT reactors can handle most of the waste that one would reasonably expect to process by this type process. There are limits to the process created by the addition of water and hydrocarbons. This is not an inherent limit; the limitation results from the large gas volumes that are produced during treatment of volatile materials that could exceed the design capacity of the offgas treatment system. It should be recognized that this is an engineering design issue and not a fundamental system problem.

DOE must provide the development organizations they fund with the performance requirements desired for the final waste forms. The comparison of the different technologies and their cost will be highly speculative as long as performance requirements are unavailable. Additionally, the developers need performance requirements so that they can establish realistic goals for their development efforts. Standardized waste materials for testing are also needed, in terms of composition, radionuclides present, and the radiological activity of the waste used for performance evaluation and testing. Standardized wastes will also be required to provide fair comparisons of the relative performance and cost effectiveness of the different treatment methods that are now approaching engineering maturity.

As indicated by the industrial application of CEP, it is presently capable of processing spent radioactive resins into the CEP molten bath. The resins are slurried, dewatered, and ground to $<1 \mathrm{~mm}$ particle size. The material is then dried to less than $10 \%$ water, pneumatically transferred to a surge tank, and fed by bottom lance into the melt bath. The feed rate is about $300 \mathrm{lb} / \mathrm{hr}$ (dry wt) excluding bound water in the resin. 


\subsection{Dust}

Dust generation, handling, and recycle is of particular concern for CEP because it operates in a reducing environment, resulting in reactive or even pyrophoric dust. Under normal operation, the gases are primarily carbon monoxide and hydrogen that carry particulate dust into a collection bag house or filter. Qualitatively, the dust generated by CEP consists of iron particulates, iron chlorides, refractory dust particles (silica, alumina, calcia), and carbon particles. Dust generation is clearly sensitive to the composition of the waste feed. Dust to the APC system is estimated to be about $5 \mathrm{~g} / \mathrm{scm}$ for organic or volatile feeds.

It is clear that dust removal, stabilization, and disposal will be required for some of the dust, however, the unit operations have not been clearly defined. Analysis of secondary waste streams, including dust, to establish an optimum waste management strategy for a variety of waste streams has not been performed.

Dust suppression has been evaluated to some degree. Operating in a pressurized mode (up to 150 psig) reduces dust generation. No parametric studies were presented, however. For some feeds, maintaining carbon concentration in the molten metal bath reduces refractory corrosion, resulting in reduced dust generation as well. No dust reactivity data were presented.

Several areas of dust management need to be better understood. The amount of iron that is carried over in addition to that as ferrous chloride needs to be understood. A transition must be made from the reactive form to a non-reactive form before the dust is incorporated into a polyethylene or other suitable matrix for disposal. The amount of this waste can appreciably affect costs.

Although some engineering design and optimization work must be performed to operate a molten metal facility effectively, much of it can be accomplished by proper designs to handle the dust. As with any facility, the shakedown and start up of the facility will provide the operating experience to improve reliability of the equipment. 


\subsection{Volatiles}

A general understanding of the volatile metal carry over into the air pollution control system now exists. Less than of the lead, zinc, and cesium can be captured in the metal phase, and about $2 \%$ can be captured downstream of the baghouse. Testing has demonstrated that most $(\sim 90 \%)$ of the lead, zinc, and cesium can be collected in the demonstration facility baghouse. Mass balance on the test data has been less than satisfactory in that individual tests provide dramatically different closure results (from $20 \%$ to $140 \%$ ), believed to be caused by bag filter holdup and some condensation resulting in plate out on system ducts upstream of the baghouse or possible leakage.

Combining several tests provides better results: about $70 \%$ closure on volatile heavy metals. MMT has undertaken a research effort to characterize and quantify the plate out on duct components and to assess proposed solutions.

Most of the chlorides injected into the system move to the APC, about half are collected in the baghouse as ferric or ferrous chloride, most of the balance is $\mathrm{HCl}$ and is collected in the caustic scrubber, or it can be partitioned to the slag phase to $5-13 \mathrm{wt} \%$ of the slag. Lead in the dust is primarily in the elemental or chloride form. MMT would like to put as much chloride in the ceramic phase as they can, subordinate to competing design or product considerations. Three advantages of maximizing chloride in the ceramic were identified: 1) reduced $\mathrm{HCl}$ in the offgas reduces corrosion in APC components; 2) partitioning chloride to the ceramic instead of as $\mathrm{FeCl}_{2}$ reduces offgas dust, dust handling, and recycle; and 3) there have been no identified adverse effects on slag durability or leachability at these concentrations and has even been shown to improve slag phase durability in some tests. However, the chloride retention is quite composition sensitive, and it remains to be proved whether chloride can be retained in the ceramic form to minimize the volume of secondary waste that must be immobilized separately to contain the volatile chloride compounds.

Chlorine contained in the waste partitions between $\mathrm{FeCl}_{2}$ in the bath, some remains in the slag layer, and the remainder enters the offgas stream as $\mathrm{HCl}$. The quantities being produced are a function of the waste type, bath conditions, slag composition, and redox characteristics of the system during operation. The resolution of these issues will be a function of the waste composition, the selection of operating design parameters, and the performance requirements of 
the final waste form.

Any sodium injected into the system may be partitioned to the metal phase, but more often it will partition to the ceramic layer as sodium glass. Normally, volatile sodium is retained in the metal phase as a sulfide until steps are taken to remove the sulfur from the bath. Data were presented that showed that sodium and potassium are partitioned to the gas handling train in the absence of sulfur or a ceramic phase.

Mercury has been injected into the demonstration plant in one pound bags. Mass balance closure was poor, showing about $20 \%$ recovery as metal, which was in the caustic scrubber.

Measurements up and downstream of the charcoal filter and subsequent analysis of the charcoal filter indicated that very little of the mercury in the APC system reached the charcoal filter. M4 is planning to capture elemental mercury and recycle it to a private company. For DOE-MLLW, mercury must be recovered as the metal for potential recycle or it must be included in the stabilization of all secondary waste streams.

In spite of the lack of adequate closure on Volatile Heavy Metal (VHM) mass balances, no technology development needs were clearly identified. MMT is confident that they can operate a system effectively and safely with the level of technical data available to them now. The pressure within the system may be positive or negative. If the pressure is positive, the assurance of no leakage external to the system is required. 


\subsection{Elemental/Radionuclide Partitioning}

The application of CEP to MLLW is complicated by the possible accumulation of materials in the metal bath and their effect on the molten metal for subsequent use. Specific calculations on tolerable accumulations are required to indicate how frequently the bath must be purged or discharged for disposal rather than recycle. Discharge could be required because of the accumulation of metals in the bath or the accumulation of radionuclides to levels unsuitable for contact handled MLLW. This can increase the overall disposal costs associated with the process.

The partitioning characteristics of elements and their respective isotopes to the metal, slag, or gas phases of CEP can, in many cases, be predicted by standard equilibrium thermodynamic calculations using relative free energies of reaction. However, there are several factors that can complicate the expected results: similarity of thermodynamic properties between species, nonequilibrium operating regimes, interspecies interactions, and reactor operating pressure. In some cases, the addition of process additives can be used to selectively partition species as discussed in the Process Chemistry section of the report (Section 7.0).

The purpose of this section is to report actual radionuclide or radionuclide surrogate processing experience to date using CEP as reported to the TRT. In the absence of experimental data, theoretical predictions will be stated as such. Some data from the bench scale processing of actual MLLW have just been made available. Initial results from the treatment of a DOE-Oak Ridge MLLW stream, West End Treatment Facility (WETF) sludge, are summarized below.

\subsection{Volatile/Semi-Volatile Species}

At the approximate $\mathrm{CEP}$ reaction temperatures of $1500^{\circ} \mathrm{C}$, the range of volatile species runs the gamut of the periodic table. At the light end of the spectrum lithium, sodium, and potassium can be expected to form semi-volatile fluorides or chlorides in the presence of fluorine and chlorine respectively. The volatility of these species can be reduced with increased operating pressure. MMT indicated that there are options to retain the sodium in the ceramic phase at levels from 5\% to $13 \%$. It is interesting to note that, in the presence of sulfur, research has verified that sodium will form a sulfide that is retained in the metal bath. In these same experimental runs (in the 
presence of sulfur), MMT determined that small amounts of sodium (approximately $5 \%$ of total sodium) were retained in the slag phase.

At higher concentrations, sulfur can be classified as a semivolatile element. Sulfur compounds are typically converted to elemental sulfur that partitions to the metal bath as a ferroalloy. As the sulfur reaches levels of $25 \%$, it starts to volatilize (see Section 7.0). Researchers gave some indication that sulfur can be partitioned to the slag phase; however, no sulfur-containing slag phase has yet been produced by MMT. Phosphorus, like sulfur, forms ferroalloys in the metal bath. Researchers have hypothesized approaches to remove phosphorus from the metal, but this research had just been initiated and the results were not available or review by the TRT.

One of the most flexible of the lighter species is chlorine. Information from MMT shows that chlorine is semi-volatile, partitioning between the slag and the gas phase. Experimental work on chlorine shows different partitioning characteristics depending on bath chemistry (see Section 7.0). Iodine, in the same VII-A group of the periodic table as chlorine, will also completely volatilize to the offgas stream.

Much research has been conducted on the behavior of certain VHMs: zinc, cadmium, cesium, mercury, thallium, and lead. Cesium-137 is a volatile radionuclide appearing in DOE waste that causes problems for a wide variety of processing technologies due to its extreme volatility and high activity. Upon entering the CEP reactor, cesium oxide is reduced to elemental cesium which then volatizes to the offgas in pure form. MMT research shows levels of approximately $1 \%$ retention in the metal bath with the remainder captured in the process baghouse. Mercury, present in many MLLW streams as mercury sulfide, is similar in that it also partitions almost completely to the gas phase.

Lead has been demonstrated to be a very volatile element at the typical CEP operating temperatures of 1500 to $1550^{\circ} \mathrm{C}$. This occurs is in spite of the fact that the boiling point of lead, $1740^{\circ} \mathrm{C}$, is at a somewhat higher temperature. However, the boiling point of lead oxide is $1482^{\circ}$ $\mathrm{C}$ and that of lead chloride is $950^{\circ} \mathrm{C}$. These facts, along with the stripping action of evolving gas, lead to almost complete removal of lead from the metal phase into the gas phase and gas handling the majority of the lead in these sample runs was collected in the process baghouse, while a very small portion precipitated in the gas cooler. Zinc (boiling point $907^{\circ} \mathrm{C}$ ) shows very similar 
behavior to lead in that the majority is partitioned to the gas handling train with very slight retention in the metal phase. One experimental run by MMT indicated one percent partitioning to the metal phase, trace levels in the ceramic, and the remainder in the process baghouse and gas cooler. Very little lead or zinc appears downstream of the process baghouse in the CEP gas handling train.

\subsection{Oxidized Species}

According to MMT researchers, typical species that partition to the slag phase include materials considered to be glass formers, uranium and similar elements, and at least one RCRA listed metal. Glass network formers oxidized to the ceramic phase to form the base components of the glass matrix include: silicon, boron, aluminum (in the presence of oxidizing co-feeds), and zirconium. Elements (and their isotopes) partitioning to the slag phase that modify the glass network structure include calcium, beryllium, titanium, thorium, magnesium, barium, yttrium, and strontium. Note that the presence of barium, a hazardous constituent (RCRA listed), in the slag dictates that the ceramic be engineered to tightly retain all species in order to demonstrate leachability characteristics that meet EPA standards. The data presented by MMT showed that all slag phase products, including those manufactured during the processing of WETF sludges, passed TCLP for all RCRA metals, including barium.

In order to achieve the largest volume reduction and most efficient disposal/reuse of the process residuals, it is desired to partition as many of the radionuclides as possible to the slag phase. Recent work by M4 on Oak Ridge West End Treatment Facility (WETF) sludge, a MLLW stream, has verified some of the theoretical predictions for partitioning of these nuclides. WETF sludge is fairly typical of DOE MLLW in terms of radionuclide content in that it contains uranium $(-233,-234,-235,-236$, and -238$)$ and trace amounts of americium-241, neptunium-237, protactinium-234, plutonium-238 and -239 , and thorium $(-228,-230,-232$, and -234). Analysis of the slag waste form produced from the processing of WETF experimentally verified partitioning of greater than $99 \%$ of the uranium to the slag phase. (The other isotopes were below detectable limits.) In addition, preliminary characterization demonstrated that greater than $99 \%$ of the total radioactivity partitioned to the slag phase. Theoretical calculations show the above isotopes and many other radioactive species (that are present in small quantities in DOE MLLW) to partition to the slag including cerium-144, niobium-95, and promethium-144. 
As previously discussed, experimental evidence shows that sodium and chlorine can be induced to partition to the ceramic phase to loading levels of approximately $10 \mathrm{wt} \%$. Similar results would be expected for lithium, potassium, and fluorine. Research continues on partitioning sulfur and technetium to the slag phase; however, no experimental evidence yet confirms this capability. The partitioning of sulfur to a slag layer is common practice in the metallurgical industries.

\subsection{Reduced Species}

Species reduced by CEP that remain in the metal phase logically include some metallic elements, thermodynamically similar elements to these, and elements that strongly react with these. Examples of the metallic elements (and their respective isotopes) include chromium, copper, manganese, iron, nickel, silver, and cobalt. Cobalt-58 and -60 are common radionuclides in DOE MLLW that can limit the lifetime of the molten metal bath due to build-up of radioactivity. Theoretical considerations predict that several other common radionuclides in DOE waste will partition to the metal phase: chromium-51, manganese-54, iron-59, rhodium-106, and tellurium125.

As discussed earlier, sodium will partition to the metal bath in the presence of sulfur. Also, sulfur and phosphorus both form ferroalloys at low concentrations that remain in the metal phase.

Technetium-99 is a common radionuclide very similar thermodynamically to nickel; therefore, it shows a strong affinity to remain in the metal phase with limited solubility in the slag. MMT is currently researching methods to partition technetium to the slag with, as yet, limited success. Researchers indicated that technetium can not yet be effectively partitioned to one phase using a single-stage CEP reactor.

Thermodynamically, in a simple system, technetium is predicted to remain alloyed with nickel. Chlorine contained in the waste can partition between $\mathrm{FeCl}_{2}$ in the bath and the slag layer, and the remainder enters the offgas stream as $\mathrm{HCl}$. The quantities produced are a function of the waste type, bath conditions, slag composition, and redox characteristics of the system during operation. The resolution of these issues will be a function of the waste composition, the selection of operating design parameters, and the performance requirements of the final waste form. 


\subsection{Process Chemistry}

Much of the following discussion of process chemistry results from experimental processing of a diazinon feed by MMT. Diazinon is a complex molecule comprised of: $65.6 \%$ carbon, $11.4 \%$ oxygen, $8.2 \%$ hydrogen, $4.5 \%$ sulfur, $4.5 \%$ phosphorus, $4.1 \%$ nitrogen, and $1.7 \%$ zinc. Material presented by MMT on process chemistry centered on the partitioning of sulfur, phosphorus, and chlorine.

\subsection{Sulfur}

Thermodynamics show that sulfur will form ferroalloys at concentrations up to $36 \%$ by weight. MMT research indicates that sulfur partial pressure is negligible for concentrations less than $25 \%$ by weight. At higher concentrations, it is possible to pull the sulfur out of the metal as hydrogen sulfide gas. CEP experience in processing ion exchange resins has shown substantial sulfur release from the metal bath at concentrations in the metal bath above $30 \%$ by weight.

\subsection{Phosphorus}

Phosphorus behaves similarly to sodium in that it will not oxidize under normal CEP operating conditions. Instead, phosphorus forms ferroalloys at concentrations up to $24 \%$ by weight. MMT believes that phosphorus will remain in the metal bath until it reaches a saturation condition not yet experimentally determined. The thermodynamics behind the phosphorus retention in the metal bath show that, at temperatures greater than approximately $1200^{\circ} \mathrm{C}$, oxygen in the metal bath will preferentially react with carbon to form carbon monoxide rather than to oxidize phosphorus. Due to the fact that this transition temperature is near the reactor operating temperature, there is some hope to engineer the process chemistry to partition phosphorus away from the metal bath to the ceramic if desired. Thermodynamic calculations also show that phosphene, a very hazardous compound of phosphorus and hydrogen, is not stable at CEP operating temperatures.

MMT researchers laid out several possible methods to partition phosphorus to the ceramic phase. The first involved maintaining the bath at low carbon concentrations to allow phosphorus oxidation. Another hypothesized approach was to use a calcium oxide-rich flux to drive phosphorus to the ceramic phase through stable calcium phosphate complexes. In addition, there 
is some evidence that complex interactions may occur between phosphorus and sulfur which have not yet been investigated. It is obvious that, if phosphorus removal from the metal phase is important for the waste being processed, then more research needs to be performed to effectively accomplish this task.

\subsection{Chlorine}

The partitioning behavior of chlorine is of interest in that it has been proven to degrade the leachability performance of some waste glasses and ceramics at higher concentrations in traditional vitrification systems. As previously discussed, in CEP chlorine partitions between the ceramic and gas phases. The gas phase portion of the chlorine may come off as different species depending on the bath composition. In nickel baths, the chlorine goes off as mainly hydrochloric acid, while in iron baths it may also volatilize as ferrous chloride that gets trapped in the gas handling train process baghouse as dust. Experimental evidence suggests that, under most operating conditions, it is likely to expect equal amounts of ferrous chloride and hydrogen chloride, or as reported by the previous Technical Review Panel, chlorine may be loaded into the ceramic phase to up to $12 \mathrm{wt} \%$ with the addition of proprietary additives. 


\subsection{Final Waste Form}

CEP produces a layer of slag on top of the metal bath. The slag composition is highly dependent on the constituents in the MLLW. Because the slag must have a viscosity below a given value in order to tap and pour, additives are likely to be needed to form a glass-like material. MMT favors the use of calcium and silicon compounds to balance aluminum oxide and obtain a reasonable operating range for the waste melt.

Recent testing on actual DOE MLLW, indicates CEP will produce a predicted glass final waste form containing radionuclides. The testing was done on wastewater treatment sludges from the West End Treatment Facility (WETF) at the Y-12 Plant. The glass waste form passed TCLP testing and met Envirocare waste acceptance criteria (WAC) requirements. This was the first step in demonstrating actual CEP treatment performance on DOE MLLW.

The disposition of volatile radioactive nuclides in CEP from MLLW has not been addressed except for cesium and its carry over into the gas train of CEP. The concentrations and level of radioactivity in effluents and in the final waste form of CEP needs to be calculated, tested, and demonstrated.

\subsection{DOE Final Waste Form Definition}

At the present time, DOE has not established a policy on the preferred final waste form required from the treatment of MLLW. Potential MLLW treatment processes will produce a variety of final waste forms that will meet existing regulatory requirements, e.g., TCLP tests.

TCLP and Product Control Test (PCT) tests do not directly address longevity of the waste form or performance measures for periods of 100 years, 500 years, 1,000 years, or 10,000 years. Until DOE establishes final waste form criteria, including performance requirements for disposal, comparisons of potential MLLW treatment processes producing different waste forms and their cost effectiveness will continue to be speculative at best. In addition, standardized classes of waste materials, both in terms of composition and radiological activity, will be needed to fairly compare the different treatment methods now reaching the final stages of development. 
The TRT recommends that DOE provide the development organizations they fund with the performance requirements desired for the final waste forms. Additionally, the developers need performance requirements so that they can establish realistic goals for their development efforts. Standardized waste materials are also needed, in terms of composition, radionuclides present, and the radiological activity of the waste used for performance evaluation and testing. Standardized wastes will also be required to provide fair comparisons of the relative performance and cost effectiveness of the different treatment methods that are now approaching engineering maturity.

Current leaching tests on DOE wastes throughout the complex to satisfy EPA's TCLP test are not considered representative of the behavior of waste forms in disposal environments. The issue is understanding the long-term leach behavior in soil and various geologic environments. The leach tests need to be understood in terms of their relationships, if any, to geochemical performance and the migration of radionuclides to groundwater, migration of residual organics, if any, to ground water, and potential intrusion scenarios at disposal sites. DOE needs to develop additional guidelines on such testing in order to standardize results for comparing leaching results of various compositions and the related potential surface area available for leaching. Further, the currently used limits for ground water concentrations should be considered relative to the degree of conservatism that should be included in the acceptance of waste forms for transport and disposal. Contractors, such as MMT, cannot acquire relevant useable information on waste forms until the DOE adopts its requirements for testing of waste forms. In the meantime, TCLP, PCT, and the ASME test will be accumulated with considerable expense until better guidance is developed by the DOE. Because high temperature treatment processes will produce a volatile fraction which must be incorporated in a low-temperature waste form for disposal. The incorporation of the variety of metals and chemicals into forms, like polyethylene, might not pose a problem. However, this has not been done and the idea should be investigated. 


\subsection{Further Research}

This section will suggest potential areas of further research that might be pursued to ensure that CEP will perform effectively on DOE waste.

\subsection{Bulk Solids Processing}

Work is needed to examine the processing of large, essentially uncharacterized feeds.

The solvent properties of the metal bath can conceivably be used to process structural members, process equipment, and non-size-reduced containers of MLLW. To accomplish this, further investigation into the methods for linking the two zones should be done, while ensuring the integrity of the CEP's environmental performance.

Work to connect both zones efficiently and reliably to ensure a sophisticated system so that, once the waste materials are in zone 2 , their compositions can be analyzed and the product formation issues become identical to those encountered when processing characterized pumpable feeds.

\subsection{Radioactivity Management}

Analyzing the complexity of increasing levels of radioactivity (including TRU and HLW) in the CEP, and the management of the radioactivity in the connected systems.

Instrumentation to measure high levels of radioactivity throughout all parts of the CEP.

Examination of the behavior of alkalis and halogens in order to more confidently model their behavior in remotely operated areas of the CEP. 


\subsection{Elemental Partitioning}

The maximum amount of chlorine that may be contained in the slag/glass phase without degrading leachability characteristics has not been firmly established.

Experimental partitioning data on isotopes present in actual DOE TRU (Transuranic) waste need to be gathered and analyzed.

Further research needs to be performed on partitioning technetium-99 from the metal phase to the ceramic phase since no effective means of doing so has yet been developed. Full-scale processing of MLLW needs to be performed to establish partitioning characteristics (that may differ slightly from bench-scale, batch-fed units) in a larger metal bath using continuous feeds.

\subsection{Process Chemistry}

The literature values need to be confirmed under MMT operating conditions.

Methods to partition phosphorus from the metal bath need to be identified and proven experimentally.

The effect of the slag layer on dust generation.

\subsection{Alternative Energy Addition}

Examine methods of adding energy to the headspace and to horizontal arms for processing of bulk solids to provide maximum reactor performance.

\subsection{Instrumentation}

To facilitate on-demand or continuous tapping of the condensed phases, operators will need on-time knowledge of bath composition and viscosity to ensure the bath has the 
requisite physical properties for product removal. Means to better monitor the viscosity of the bath are required, which in turn requires a database for conversion of glass phase chemistry and temperature to viscosity.

\subsection{Product Quality}

Experiments with CEP to improve the ability to partition depleted uranium to either oxide form or the metal by modifying the operating chemistry of the bath.

\subsection{Containment Systems}

Tests after addition of means for cooling the refractory systems to allow a layer of material to skull on the surface, decreasing the likelihood of attachment by the melt, should result in increasing refractory life.

Testing in CEP of Russian designs (which are not operated in a sealed, reducing environment) that replace refractory with cooled metal systems in ways that minimize energy loss from the bath.

Methods of containment to prevent in-leakage which could cause safety problems should be investigated. These are simply design and operating options and do not require development. The preferable operating mode for DOE is to operate the unit under negative pressure rather than under a positive pressure as is now the plan. 


\section{Summary of Recommendations}

\subsection{General Recommendations}

1. Given the favorable results of MTT's work on CEP over the last year and given the implementation of the MMT/M4 industrial venture, the TRT found the CEP technology to be sufficiently developed that MMT should be able to compete in the marketplace by adapting CEP for processing DOE's various types of mixed low level waste (MLLW).

2. Although additional development work is needed for specific applications, work on those applications should address the specific needs at the particular site possessing the waste.

3. The TRT, however, believes that the application of CEP to specific wastes other than the broad category of MLLW has not been fully explored.

4. Assessment of these applications is needed in comparison to other competing processes. Applications to TRU waste and to HLW are not fully developed or explored.

\subsection{Positive Attributes Noted}

Additionally, the TRT noted that CEP offers:

processing of pumpable MLLW and shredded MLLW to destroy the organic constituents

processing of MLLW under reducing conditions that will not produce dioxins or furans for release to the atmosphere.

accumulation of metals that can be withdrawn and recycled for reuse as long as the accumulated mixture of metals keeps the composition of the iron within acceptable limits for use, e.g., to fabricate containers for disposal of the immobilized ceramic waste

accumulation of the more volatile metals, e.g. mercury, in the metallic form for potential purification and recycle 
accumulation of incoming lead mostly as dust from the baghouse presumably as chloride which must be incorporated into polyethylene or other suitable waste form

production of a slag type waste form that passes TCLP tests and renders the waste to be a radioactive waste for disposition by the DOE

production of a separate dust and salt streams that may be incorporated into a suitable waste form (This is typical of all current thermal treatment systems that are candidates for MLLW treatment.)

\subsection{Uncertainties about CEP}

However, CEP has the following uncertainties:

-- processing of shredded waste will likely require feeding on the top of the molten metall layer and will require a second stage to destroy the organic vapors from the first stage

-- all of the design concepts required for operation with radioactive material have not been assembled or tested. For example, the containment and melt discharge systems and their remote operational requirements (This is similar to most other competitive concepts that also have notdemonstratedd this step.)

-- the life of refractory liner varies from an estimated 90 days at the melt interfaces to 180 days in the metal melt or vapor phase. Other parts must be designed for replacement more often in highly agitated zones, e.g., the tuyere nozzle inlet every 30 days

-- although operation under pressure (175 psig) is thought to be somewhat better to control dust carry over from the melter, operations can also be conducted under atmospheric conditions that allow the customary slightly negative pressures within the system for containment of radionuclides. The designer must trade off 
pressurized operating concepts and the attendant ASME code requalifications with negative pressure concepts that potentially can have air in leakage and the potential for explosive gases within the system unless shrouded externally with inert gas atmosphere

-- $\quad$ the composition of the slag preferably using calcium and silicate needs to be more precisely defined to establish whether the compositions can be maintained or adjusted to the needed viscosity for tapping into a final waste container

-- $\quad$ the endothermic nature of the reaction may require supplemental heat besides the induction heating of the melt, e.g., in the top of the reaction chamber particularly if top feeding of the waste is used

-- the amount of sorting and control needed to maintain the molten metal within a useable composition range as varying metals are processed through the unit, particularly, the introduction of copper

-- $\quad$ the amount of dust and the scrubber salts that must be incorporated into suitable waste form needs quantification

-- $\quad$ the chemical complexity in the metal bath and slag layers introduces control questions that will require good characterization of incoming waste or readily available analytical support to assure adjustments are properly made for both the metal and the slag phases

-- processing of whole drums appears to be an unlikely option, but shredded waste up to 2-5 inch size may be possible if fully tested

-- the absence of DOE policy on waste forms creates an uncertainty concerning the value/benefit and acceptability of final products from the CEP as well as all other treatment processes. Appropriate testing methods for use in performance assessment of disposal sites is needed. 


\subsection{Follow Up of TRP Issues}

In its 1995 report, the Technical Review Panel (TRP) raised several issues:

\begin{tabular}{|c|l|l|}
\hline \multicolumn{2}{|l|}{ TRT OBSERVATION OF ISSUE RESOLUTION OF TRP ISSUES } \\
\hline \hline 1 & Inventory data: equilibrium and disruption & $\begin{array}{l}\text { Numerous runs on diff. chemicals and products to } \\
\text { be made being performed }\end{array}$ \\
\hline 2 & Pyrophoric nature of offgas particulates & $\begin{array}{l}\text { Methods to control dust being developed; use of } \\
\text { inert gas during maintenance }\end{array}$ \\
\hline 3 & Small feed size & Addition of 2nd bath or zone allows 2-5" feed size \\
\hline 4 & Probable regulation as a thermal unit & California and possibly TN, regulating as recycler \\
\hline 5 & Operation on rad waste needs much devel. work & Work has begun on IER by SEG and MMT \\
\hline 6 & Flowsheets needed to manage secondary wastes & Not made available to the TRT \\
\hline 7 & Longer refractory life needed & Tests underway; refractory life now estimated to be \\
\hline 8 & $\begin{array}{l}\text { Tapping methods other than rotating the bath must be } \\
\text { developed }\end{array}$ & An arrangement is being developed \\
\hline
\end{tabular}




\title{
APPENDIX A
}

\section{BIOGRAPHIES OF THE TECHNICAL REVIEW TEAM}

\author{
Carl R. Cooley \\ Office of Science and Technology \\ Office of Environmental Management \\ U.S. Department of Energy
}

EDUCATION

M.S. Chemical Engineering, University of Idaho, 1958

B.S. Chemical Engineering, Kansas State, 1950

\section{CERTIFICATIONS}

\author{
Licensed Professional Engineer, Washington, 1960
}

\section{CURRENT PROFESSIONAL HIGHLIGHTS}

Currently, Mr. Cooley is the Senior Technical Advisor to the Assistant Deputy Secretary for Environmental and Waste Management, Department of Energy. He has 43 years of professional experience in the waste management and chemical industry; 14 years with General Electric at Hanford Plant, Richland, Washington; five years with Battelle Memorial Institute at Hanford; five years with Westinghouse Hanford Co. at Hanford; and eighteen years Federal service with the Department of Energy and its predecessors in Washington, D.C. He is a member of the American Institute of Chemical Engineers and has served as the local program chairman and national session chairman. Mr. Cooley serves as a consultant at waste management meetings and speaks regularly at national and local meetings. He has received numerous outstanding performance awards from the Department of Energy.

\section{EXPERIENCE}

Professional Employment: 43 years

Senior Technical Advisor to Assistant Deputy Secretary for Environmental and Waste Management, Department of Energy. Performed systems analysis and engineering studies on environmental remediation and waste treatment technologies and associated air pollution control, and waste disposal. Conducted cost savings analysis for selection and use of technologies. Organization and coordination of peer review groups. Coordination with EPA and DoD programs on implementing the Federal Strategic Environmental Research and Development Program. Implementation and direction of DOE 
technical programs and projects for waste management, disposal, spent fuel storage, environmental and waste management technology and depleted uranium reuse. Provided recommendations of technical plans and options for remediation, waste treatment/incineration low-level and high-level radioactive waste treatment, storage and disposal using cold and radioactive pilot plant demonstrations. Dry spent fuel storage. High-level waste geologic disposal technology and subseabed and space disposal options. Radioactive pilot plant design, construction and operation for spent fuel reprocessing, uranium recovery, plutonium and isotope recovery. Coordination of international activities and projects with other countries, the International Atomic Energy Agency, etc. Design, construction, operation and decontamination of radioactive pilot plants for isotope recovery and spent fuel reprocessing. Conception and development of chemical processes for uranium recovery, plutonium recovery, isotope recovery, waste stabilization and disposal.

\section{ADVISORY ACTIVITIES}

1980 - present

-Technical consultant to the International Atomic Energy Agency for waste management in Thailand and Indonesia, 1994.

.DOE Technical Review of waste treatment technology options, 1994.

.DOE Technical Review of molten metal as technology for recycle and waste treatment, 1994.

-Technical Review of Molten Salt Oxidation integrated waste incineration systems and Rocky Flats Fluidized Bed Incinerator Program, 1993.

IAEA International Waste Advisory Committee, 1992.

DOE Technical Review of technological needs for the Fernald environmental restoration program, 1992.

-IAEA Technical Consultant to Ireland on radioactive waste management, 1991.

IAEA advisor for International Waste Advisory Committee to review IAEA waste management program plans, 1991.

. OECD/Nuclear Energy Agency (Paris) Ad hoc committee on planning for environmental restoration and waste minimization, 1991.

-Invitational participation in the Commission of European Communities Five Year Plan Meeting, 1990.

- Office of Technology Development delegate to Radioactive Waste Management Committee of OECD/Nuclear Energy Agency, 1990

.U.S. participant in Radioactive Waste Management Committee of OECD/Nuclear Energy Agency, 1989.

-IAEA technical advisor for Waste Management Advisory Program mission to mainland China and Korea, 1988.

-IAEA annual meetings of the Technical Review Committee for document publication and program plans and Pre - 1980 participant in OECD/Nuclear Energy Agency Radioactive Waste Management, 1980 - 1988.

U.S. delegation for the International Fuel Cycle Evaluation of Waste Management 
Design for uranium hexafluoride conversion vitrification of waste, isotope recovery and low-level waste treatment

\author{
Scott G. Boeke \\ Program Manager \\ Technology Development and Transportation Group \\ Oak Ridge Operations Office \\ U.S. Department of Energy
}

\title{
EDUCATION
}

M.S. Nuclear Engineering, University of Michigan, 1994

B.S. Ceramic Engineering, University of Illinois, 1992

\section{CURRENT PROFESSIONAL HIGHLIGHTS}

Mr. Boeke is responsible for Technology Development activities at Oak Ridge in the areas of robotics and characterization activities. Responsibilities include monitoring contractor performance in these areas and coordination activities between contractor and headquarters program managers. He is also coordinator for several mixed waste treatment technology demonstrations.

\section{EXPERIENCE}

Professional Employment: 4 years

Program Manager, Technology Development and Transportation Group, Oak Ridge Operations Office, U.S. Department of Energy. Program Manager for the following EM-50 programs at Oak Ridge: Robotics Technology Crosscutting Program and the Characterization, Monitoring, and Sensor Technology Crosscutting Program. Responsible for oversight of contractor personnel engaged in research and development in support of environmental management needs. 1995-Present.

General Engineer, Office of Site and Facility Transfer (EM-64), Headquarters, U.S. Department of Energy. Responsible for implementing the DOE Project Management System in EM-64 and assessment of the DOE Performance Indicator Program at Richland and Idaho. Completed varied assignments including participating in the EM-60 Rocky Flats Plan pre-turnover review and DOE Intern Working Group. Completed DOE Facility Representative Advanced Nuclear Course at the Rocky Flats Plant and Livermore, Califormia. 1993-1995.

General Engineer, Office of New Production Reactors, Office of Modular High Temperature GasCooled Reactor, Reactor Design Division (NP-63), Headquarters, U.S. Department of Energy. Assisted in program management for research and development activities on reactor structural 
materials, reactor graphite and ceramics, and vessel materials. Completed DOE-sponsored comprehensive 14-week engineering course at Virginia Tech. 1992-1993.

Edwin A. Korzun

U.S. Department of Energy

Savannah River Site

EDUCATION

Ph.D. Environmental Science, Florida Institute of Technology, 1993

M.S. Environmental Science, Florida Institute of Technology, 1986

B.S. Major -- Chemistry, ACS Certified, Minor -- Physics, The University of Vermont, 1956

\section{CURRENT PROFESSIONAL HIGHLIGHTS}

Edwin Korzun is an environmental scientist with 40 years of experience in the environmental waste and industrial, technical fields. He has authored or co-authored over 26 publications and presentations. In addition, Mr. Korzun conducted 14 specific industrial research studies which resulted in internal industrial research publications from 19601970 for the Silicone Products Department of General Electric Company. More recently, from 1987 to 1993, he completed 11 funded research studies at the Florida Institute of Technology. As a Short-Term Consultant, his clients include Fluid Mechanics, FAR Research, and Pilot Fibers. From 1988 to 1989, he served on the Brevard County Florida Hazardous Waste Management Advisory Committee. In 1990, he served as Technical Advisor for the EPA Region IV and Region V Pollution Prevention Project. He is an active member of the ACS, the ACS Division of Environmental Chemistry, and the Air and Waste Management Association (AWMA); an affiliate member of the International Union of Pure and Applied Chemistry (IUPAC); and a Diplomate of the Institute of Hazardous Material Management.

\section{EXPERIENCE}

Professional Employment: 40 years

General Physical Scientist and Waste Minimization Specialist, Program Management and Coordination Division, U.S. Department of Energy, Savannah River Site, (DOE-SR), South Carolina. Provided support for the development and documentation of the DOE-SR Pollution Prevention Policy and issuance of the Implementation Policy Manual. Coordinated acceptance and implementation of the site wise Pollution Prevention/Waste Minimization program and conducted assessments of program implementation progress. Coordinated, planned, and moderated a complex wide peer review of vitrification technologies funded by both DOE sites and Headquarters. The vitrification technologies selected for review were those considered most suitable for long term stabilization of 
Transuranic, Mixed Transuranic, and Mixed Low Level types of radioactive waste in either glassy or ceramic matrices.

Executive Director, Research Center for Waste Utilization, Florida Institute of Technology (FIT), Melbourne, Florida. Coordinated and assisted in obtaining research grants totaling over $\$ 2$ million dollars. Coordinated research efforts of groups consisting of 4-14 Ph.D. researchers and graduate students. Interacted with local, state, and federal regulatory agencies and the private sector. Managed the research budgets and maintained time lines for project completion. 1990-93.

Acting Executive Director, Research Center for Waste Utilization, FIT. Conducted original research on the energy, environmental, and physical-chemical aspects of waste related environmental studies. Generated proposals with total values of over $\$ 1,000,000 / \mathrm{yr}$. Coordinated and provided support for the activities of 14 senior members conducting original research. Research coordinator for a $\$ 500,000$ grant, studying the use of stabilized resource recovery ash in the construction of marine artificial reefs. $1988-1990$.

Associate Director, Florida Center for Solid and Hazardous Waste Management (FCHWM), a consortium of five state and two private Universities in Florida, located at the University of Florida. Coordinated Florida Institute of Technology's solid and hazardous waste management programs with state programs. Aided in the development of the Center research programs and budgets. Provided liaison with local and state agencies and industry to insure fulfillment of research needs at the state level. Assisted in technology transfer from the Center to meet local and regional needs. Provided recommendations for research project funding to members of the state legislature. Reviewed research proposals. Presented technical information to the members of the Florida Environmental Regulatory Commission, when requested by the Florida Department of Environmental Regulation. 1988 - 1993

Adjunct Faculty, FIT. Instructed Chemistry and Water Treatment courses to undergraduates. 1987 1993.

Member, Florida High Technology and Industry Council, Solid Waste Management Task Force, Office of the Governor. Provided a study of the effect of increasing recycle rates on recycle markets for paper, aluminum, steel, glass, plastics, and tires in Florida. Determined market constraints and opportunities. Recommended legislative actions to assist the state of Florida in meeting its solid waste recycling goals. Interacted with material producers and the recycle industry to insure consideration of their views. 1988- 1989.

Research Scientist II, Research Center for Waste Utilization, FIT. Conducted research to investigate sources and fates of solid and hazardous wastes in Florida. Directed research efforts of graduate students and computer specialists. Quantified the generation of hazardous and solid waste in the public and private sectors. Evaluated hazard potential of waste materials and current cost of waste management. Proposed recommendations for the application of commercially available technology to 
reduce waste management impact on the environment. Documented research results for periodic submission and briefings to the Florida Center for Solid and Hazardous Waste Management, The Florida Department of Environmental Regulation, and the U.S. Environmental Protection Agency. Prepared a model county ordinance for hazardous waste management in Brevard County. 1986 1993.

Quality Systems Engineer, Silicone Products Department, General Electric Co. (GE). Developed a total quality-control system by integrating quality standards for purchased raw materials in process control and finished-product quality requirements. Interfaced with customers, suppliers, marketing, and manufacturing to develop guidelines and strategies for economic provision of silicone products meeting customer quality requirements. $1968-1970$.

Quality Control Engineer, Silicone Products Department, GE. Controlled the quality of silicone monomers, polymers, resins, surfactants, and lubricating oils. Investigated customer complaints and interfaced with customers and production engineers to resolve product quality problems. Established in-process and finished-product quality specifications to meet end-use requirements. Developed and documented statistical quality control reports for management. 1968 - 1968.

Sales Engineer, Silicone Products Dept., GE in Boston, MA. Dept. representative to purchasers and users of silicones in the electrical, chemical, and aerospace industry in Massachusetts. Recommended silicone materials to meet customer application needs. Provided technical assistance during initial production and thereafter. Identified business forecasts and opportunities. Suggested new directions for product research and development. $1963-1966$.

Research Chemist, Silicone Products Dept., GE. Conducted research and development of organosilicone polymers for the purpose of developing new silicone elastomers. Devised novel and commercially successful cross-linking techniques, the first self-bonding silicones, high-release silicone roll covers, compliance cable insulation, and powder process methods. Provided technical assistance to potential customers during production trials of newly developed products and assisted manufacturing engineers during scale-up from the laboratory to full plant production operations. $1960-1963$.

Navigator and Electronic Warfare Officer, B-52 Strategic Bomb Squadron, Loring, A.F.B., U.S. Air Force. Responsible for navigation, defensive and offensive electronic warfare, and communications. Administrative duties included Weapons Control Officer, Squadron Adjutant, and Public Information Officer. Completed military schools in navigation, electronics, electronic warfare, B-52 crew training, and survival. Cleared to top secret. $1957-1960$.

Process Engineer, Republic Steel Corp., South Buffalo Works. Investigated the transfer of Mn, S, and $P$ between the melt and slag phase during the basic oxygen steel-making process. Determined 
techniques for shifting Mn equilibrium to enhance removal of $\mathrm{S}$ and $\mathrm{P}$ from ferrous alloys based on thermodynamic, and micro and macro physical metallurgical techniques. Developed melt and hot working process changes to reduce production costs and improve finished-product quality. Developed improved ingot casting practices to improve quality. 1956 - 1957.

William Anthony Owca

U.S. Department of Energy - Idaho

\section{EDUCATION}

M.S. Mechanical Engineering, University of Nebraska

B.S. Engineering, University of Iowa

B.S. Biology, Creighton University

\section{EXPERIENCE}

Professional employment: 14 years

Department of Energy, Idaho Operations Office. Participated with the support team in preparation of High Level Waste Tank Remediation Focus Area strategic and management plan. Decision Process Support Team Leader for Volume 1 of the National Spent Fuel Program and INEL ER\&WM Environmental Impact Statement. Managed Laboratory Directed Research and Development Programs for two Strategic Planning Units: (1) Material Recovery and Reprocessing and (2) Environmental Engineering Center. Evaluated treatment, storage and disposal options, processes, regulatory factors, and strategies for high-level waste, Transuranic Waste, and mixed z-contaminated low-level waste. June, 1991 - present.

Westinghouse Idaho Nuclear Company, Idaho Falls, Idaho. Performed NEPA evaluations and established permit requirements for all Idaho Chemical Processing Plant (ICPP) projects. Prepared and reviewed Categorical Exclusions, Environmental Assessments, and environmental documentation plans for plant projects. Prepared environmental evaluations for plant projects and plant operations issues. Prepared spent fuel processing engineering study. February, 1990 - June, 1991.

Westinghouse Hanford Company, UNC Nuclear Industries, Richland, Washington. Project engineering for $\mathrm{N}$-Reactor plant projects: prepared engineering studies, design changes, procurement specifications; performed technical reviews of vendor submittal; managed system procurement, fabrication, installation, and testing. March, 1986 - November, 1988. 
EG\&G Idaho, Inc., Idaho Falls, Idaho. Planned, performed, and coordinated thermal-hydraulic testing of system components and integrated systems stimulating nuclear reactors or reactor components. Analyzed test results and prepared summary reports. July, 1980 - February, 1986.

\author{
Michael M. Torbert \\ Headquarters Program Manager \\ Office of Central Operations -- Oak Ridge \\ Office of Waste Management \\ U.S. Department of Energy
}

EDUCATION

B.S. Mechanical Engineering, Pennsylvania State University, 1968

B.A. Liberal Arts, Pennsylvania State University, 1968

\title{
CERTIFICATIONS
}

School of Environmental Excellence, 1991

Bettis Reactor Engineering School, 1969

\section{CURRENT PROFESSIONAL HIGHLIGHTS}

Mr. Torbert is responsible for providing the Waste Management Program guidance and technical management for the waste operations at the Y-12 Plant in Oak Ridge, Tennessee. Responsibilities include planning, direction, and defending the planned and on-going waste management program; the treatment, storage, and disposal of radioactive, hazardous, mixed, and sanitary waste. He managed both the headquarters approval of the justification for mission need of a regional Mixed Waste Treatment Facility in Oak Ridge, Tennessee and the headquarters operational readiness review, start-up, and initial operations of the Toxic Substances Control Act (TSCA) Incinerator in Oak Ridge, Tennessee. He is responsible for mixed waste issues related to the Oak Ridge Reservation sites. Mr. Torbert co-authored the paper, 'Radioactive Mixed Waste Treatment Facilities at Department Energy Sites', presented at the Seventh Annual DOE Model Conference in Oak Ridge, Tennessee.

\section{EXPERIENCE}

Professional Employment: 27 years 
Headquarters Program Manager, Waste Management, Oak Ridge Operations Division, Office of Eastern Waste Management Operations. Responsible for the planning, direction, and execution of the treatment, storage, and disposal of radioactive, hazardous, mixed, and sanitary waste. He is a member of the Core Management Group for the new approach to technology development for the Environmental Management (EM) Program. 1990 - present.

Technical Director and Program Manager for several contracting firms providing diverse technical services to the Department of Defense and the State Department. Services included maintaining secure communications for the State Department, designing mine neutralization systems, reverse engineering for the Navy Foreign Materiel Program, and design and licensing support activities for the South Texas Project nuclear power plant. 1973 - 1990.

Member of the Headquarters Technical Staff, Nuclear Power Program, U.S. Navy. Responsible for the operation of two submarine prototype reactor facilities and assisted with the first-time refueling of an advanced large surface ship reactor. 1968 - 1973. 


\author{
Gary D. Knight \\ Senior Policy Advisor \\ Waste Policy Institute
}

\title{
EDUCATION
}

Completed $1 / 2$ the course work for MBA in Business-Government Relations, American University, Washington, D.C., $1974-75$

Masters in Public Administration, American University, Major -- Governmental Management; Minor -- Organizational Theory and Behavior, 1974

B.S., U.S. Naval Academy, Annapolis, MD, Major -- Engineering; Minor -- Management \& Leadership, 1970

\section{CURRENT PROFESSIONAL HIGHLIGHTS}

Mr. Knight is a skilled practitioner in the national public policy arena and a successful manager at the highest levels of the Federal government. He has spent a career interpreting technology to politicians and policy makers and in interpreting the political process to technologists.

\section{EXPERIENCE}

Professional Employment: 25 years

Senior Policy Advisor, Waste Policy Institute, Gaithersburg, MD. In addition to duties enunciated below, serves the Institute by coordinating with and providing lines of communication to senior policy makers in the Department of Energy and other companies. In addition to policy, provides input into possible fruitful lines of new business and executive recruitment. June - present.

Served as facilitator/staff secretary for following Office of Technology Development technical reviews: DOE Technical Review of waste thermal treatment technology options, 1994; DOE Technical Review of molten metal as technology for recycle and waste treatment, 1994; Technical Review of Molten Salt Oxidation integrated waste incineration systems, 1993; Rocky Flats Fluidized Bed Incinerator and Air Pollution Control Program, 1993; and DOE Technical Review of technological needs for the Fernald site environmental restoration program, 1992. Author of a summary report on OTD study results on options for recycling and reuse of Depleted Uranium.

Program Manager, Waste Policy Institute, Germantown, MD. Provided management, policy, strategic planning and technical advice and support to the Office of Technology Development of the Department of Energy's Office of Environmental Restoration and Waste Management (which is 
charged with cleaning up the nation's nuclear weapons sites). March, 1993 - June, 1994

Senior Administrative Specialist/Senior Engineer (Consultant), NJG, Inc., Germantown, MD. Provided management, policy, strategic to the Environmental Restoration and Waste Management Office of the U.S. Department of Energy, the Army Corps of Engineers and NASA. Provided lines of communication to key decision makers on Capitol Hill and the Office of Management and Budget (OMB). October, 1991 - February, 1993.

Deputy Assistant Secretary for House Liaison, U.S. Department of Energy, Washington, D.C. Headed a staff (with a $\$ 1.5$ million budget) of fourteen, including twelve Hill liaisons representing a $\$ 20$ billion Cabinet Department before the U.S. House of Representatives. October 1989 - October, 1991.

Lobbying Consultant, Multinational Business Services, Inc., Washington, D.C. Provided a legislative capability to this regulatory/trade-oriented consulting firm headed by a former Deputy Director for Regulatory Affairs at OMB for Fortune 500 clients including General Motors, AT\&T and IBM. October, 1988 - October, 1989.

Director, Federal Affairs, Edison Electric Institute, Washington, D.C. Served as the principal liaison between the Institute, representing the investor-owned electric companies of the nation, and the Federal government with a staff of four (including consultants). May, 1986 -October, 1988.

Expert Consultant (Special Assistant) to the Deputy Assistant Secretary for Security Affairs, Defense Programs, U.S. Department of Energy, Washington, D.C. Served on the staff of the Deputy Assistant Secretary who has responsibility for the security of not only all DOE headquarters and field facilities, but also of the Department's nuclear weapons complex, including management responsibility for a 5000-man guard force. Served on a six-man Secretarial Task Force (the Special Project Team) to examine the strengths and weaknesses of the security of the Department's nuclear weapons complex. July, 1985 - March, 1986.

Director, House Relations, U.S. Synthetic Fuels Corporation, Washington, D.C. Responsible for all communications with and activities involving the U.S. House of Representatives for this $\$ 20$ billion quasi-public corporation, established by Congress to help develop a domestic synthetic fuels capability. Oversaw a staff of five. Directed indirect lobbying efforts and set legislative strategy on numerous attempts to divert SFC funds to other purposes and in 1984 helped to hold an imminent $\$ 10$ billion rescission attempt to $\$ 5$ billion, as well as an almost-successful effort to reinstate tax credits for synthetic fuels projects. August, 1981 - July, 1985.

Assistant to the President, American Mining Congress, Washington, D.C. Reported directly to the Chief Executive Officer of this major national trade association on policy-making, legislative, 
political, organizational and managerial matters affecting the domestic mining industry. Played a major policy-making and implementing (lobbying) role on energy, environment and natural resources issues including synthetic fuels, energy "fast track" (Energy Mobilization Board), public lands, wilderness, strategic minerals, "Superfund", clean air, utility oil "Backout" and regulatory reform legislation. May, 1979 - July, 1981.

Director, Environment and Land Policy, Chamber Commerce of the United States, Washington, D.C. Became one of the senior industry policy-makers and lobbying strategists in Washington on issues relating to natural resources and the environment (including impacts on energy development), with a staff of eight. Staff Executive of the Chamber's Committee on the Environment, comprised of thirtyfive vice presidents for environmental affairs from major corporations and trade associations, which develops national policy positions for the U.S. business community on environment and natural resources issues. Widely published, quoted in the national media and sought as a speaker on environmental issues as a national business spokesman at many major national forums, including the 1978 series of national debates on the 1977 Clean Air Act Amendments sponsored by the Air Pollution Control Association. Author of a 30-minute slide presentation on the Clean Air Act and of many articles on environmental issues. April, 1974 - May, 1979.

Assistant for Legislative Affairs, U.S. Department of Housing and Urban Development. Congressional relations and liaison between the Department and Congress. September, 1973 - April, 1974.

Legislative Assistant to Hon. Norman F, Lent (R-NY). Legislation, legislative policy, research and speech writing, special projects for Freshman Member who later ascended to be ranking Member of House Energy and Commerce Committee. February, 1972 - January, 1973.

- U.S. Naval Officer. Aviator and Personnel Officer with Top Secret Clearance. Medically retired as LTJG due to disabling auto accident. June, 1970 - November, 1971.

Elected to three four year terms on the Falls Church City Council, including one two-year term as Vice Mayor by his colleagues. Among his other accomplishments, he chaired the Personnel Policy, controlling $2 / 3$ of the City's $\$ 20$ million budget; he directed a ten-year effort to revitalize and beautify the City's downtown; he was appointed by three successive Governors to the Governor's Advisory Commission on the Potomac River Basin; chaired for 3 years the Water Resources Planning Board of the Wash. Metro. Area Council of Governments; chaired other committees on cable TV, sign ordinance, noise ordinance, capital improvements, legislative policy, and All-America City competition. 
Tuesday, 1/23/96

11:00 Introduction, Summary

11:15 Q-CEP Facility Overview

12:30 Lunch

1:00 Bulk Solids

3:00 Break

3:15 R*Partitioning

4:45 Process Chemistry Issues

6:00 Adjourn

Wednesday, $1 / 24 / 96$

\section{8:30 Dust and Volatiles}

11:30 Containment

12:30 Lunch

1:00 Final Form

1:30 Product Removal

2:30 Instrumentation

3:00 Adjourn
Gatto, Payea

Stewart

Navarro-Valenti

Lowen, Herbst

Griffin

Konduri, Black

Griffin, Smelick

Griffin

Griffin

Mathieson

Griffin

Payea 
Carl Cooley, U.S. DOE, EM-50

Ed Korzun, U.S. DOE-SR

Michael Torbert, U.S. DOE-EM-34

Scott Boeke, U.S. DOE-OR

Bill Owca, DOE-ID

Bill Huber, DOE-METC

Gary Knight, WPI

Brian Payea, MMT

John Zimmerman, MMT

Alison Harrington, MMT

Bob Sameski, M4

Leslie Mayes, M4

Eric Lowen, MMT

Larry Petri, MMT

Gary Stewart, MMT

Kathi Mahoney, MMT

Tom Griffin, MMT/FR

Bashar Zeitoon, MMT

Vic Gatto, MMT

Michael Baker, M4

Gene Smelik, MMT

Martha Black, MMT 
APPENDIX D

\section{ACRONYMS AND ABBREVIATIONS}

$\begin{array}{ll}\text { APC } & \text { Air pollution control } \\ \text { BDAT Best demonstrated available technology } \\ \text { BIF } & \text { Boiler and Industrial Furnace } \\ \text { CAA } & \text { Clean Air Act } \\ \text { CEM } & \text { Continuous emissions monitoring } \\ \text { CEP } & \text { Molten Metal Technology's Catalytic Extraction Process } \\ \text { CERCLA } & \text { Comprehensive Environmental Response, Compensation, and } \\ & \text { Liability Act } \\ \text { CFR } & \text { Code of Federal Regulations } \\ \text { CH } & \text { contact-handled } \\ \text { D\&D } & \text { Decontamination and decommissioning } \\ \text { DoD } & \text { U.S. Department of Defense } \\ \text { DOE } & \text { U.S. Department of Energy } \\ \text { DOE-ID } & \text { U.S. Department of Energy Idaho Operations Office } \\ \text { DOE-METC } & \text { DOE Morgantown Energy Technology Center } \\ \text { DRE } & \text { Destruction removal efficiency } \\ \text { EM } & \text { DOE's Office of Environmental Management } \\ \text { EPA } & \text { U.S. Environmental Protection Agency } \\ \text { ER } & \text { DOE's Office of Environmental Restoration (EM-40) } \\ \text { ES\&H DOE's Office of Environment, Safety, and Health } \\ \text { FFCA } & \text { Federal Facilities Compliance Act } \\ \text { HEPA } & \text { High-efficiency particulate air (filter) } \\ \text { HQ } & \text { headquarters } \\ \text { IAG } & \text { Interagency agreement } \\ \text { INEL } & \text { Idaho National Engineering Laboratory } \\ \text { ITTS } & \text { Integrated Thermal Treatment System } \\ \text { KO27 } & \text { Toluene disocyanate wastes (under RCRA) }\end{array}$




\section{ACRONYMS AND ABBREVIATIONS (continued)}

$\begin{array}{ll}\text { LDR } & \text { Land Disposal Restrictions (RCRA) } \\ \text { LLW } & \text { Low-level (radioactive) waste } \\ \text { MACT } & \text { Maximum Achievable Control Technology } \\ \text { MAWS } & \text { Minimum Additive Waste Stabilization } \\ \text { MLLW } & \text { Mixed low-level (radioactive) waste } \\ \text { MMT } & \text { Molten Metal Technology, Inc. } \\ \text { MWIR } & \text { Mixed Waste Inventory Report } \\ \text { NRC } & \text { U.S. Nuclear Regulatory Commission } \\ \text { NEPA } & \text { National Environmental Policy Act } \\ \text { NOx } & \text { oxides of nitrogen } \\ \text { ORNL } & \text { Oak Ridge National Laboratory } \\ \text { ORO } & \text { U.S. DOE Oak Ridge Operations Office } \\ \text { OSHA } & \text { Occupational Safety and Health Administration } \\ \text { OTD } & \text { DOE's Office of Technology Development (EM-50) } \\ \text { PCB } & \text { Polychlorinated biphenyls } \\ \text { PEIS } & \text { EM's Programmatic Environmental Impact Statement } \\ \text { PIC } & \text { Product of incomplete combustion } \\ \text { PLCC } & \text { Planning level life-cycle cost } \\ \text { PPA } & \text { Pollution Prevention Act of 1990 } \\ \text { Ppmv } & \text { Parts per million (by) volume } \\ \text { ppmw Parts per million by weight } \\ \text { PRDA } & \text { Program Research and Development Announcement } \\ \text { RCRA } & \text { Resource Conservation and Recovery Act } \\ \text { R\&D } & \text { research and development } \\ \text { RDDT\&E } & \text { Research, development, demonstration, testing \& evaluation } \\ \text { RH } & \text { remote-handled } \\ \text { SCC } & \text { Secondary combustion chamber } \\ \text { SOx } & \text { oxides of sulfur } \\ \text { SRS } & \text { U.S. DOE Savannah River Site Operations Office }\end{array}$




\section{ACRONYMS AND ABBREVIATIONS (continued)}

TCLP Toxicity characteristic leaching procedure

TLCC Total life cycle cost

TRP Technical Review Panel (to evaluate CEP for EM in 1995, draft report never published)

TRT Technical Review Team (to evaluate CEP for EM in 1996)

TRU Transuranic

TSCA Toxic Substances Control Act

VOCs Volatile organic compounds

WM DOE's Office of Waste Management (EM-30) 